\title{
Hubungan Mutu Pelayanan Keperawatan dengan Tingkat Kepuasan Pasien di Ruang Asoka RSUD Dr. R. Koesma Tuban
}

\author{
Tiara Putri Ryandini ${ }^{1}$, Lukman Hakim ${ }^{2}$ \\ ${ }^{1,2)}$ STIKES Nahdlatul Ulama Tuban, \\ Email: 'tiara.putriryandini16@gmail.com,lukman@stikesnu.com
}

\begin{abstract}
ABSTRAK
Keadaan kurangnya tingkat kepuasan pasien terjadi karena tuntutan kebutuhan pasien semakin meningkat, namun tidak diiringi dengan perbaikan tindakan perawat. Apabila pasien merasa tidak puas terhadap suatu pelayanan yang disediakan, maka pelayanan tersebut dapat dipastikan tidak efektif dan tidak efisien. Hal ini terutama sangat penting bagi pelayanan publik. Penyelenggaraan pelayanan kepada masyarakat sebagai mana yang dilakukan RSUD dr. R. Koesma Tuban, perlu mendapatkan perhatian, khususnya dalam kualitas pelayanan agar sesuai dengan kebutuhan dan harapan masyarakat. Penelitian ini memfokuskan pada mutu pelayanan keperawatan dan tingkat kepuasan pasien di Ruang asoka RSUD dr. R. Koesma Tuban. Tujuan: Penelitian ini bertujuan untuk mengetahui hubungan mutu pelayanan keperawatan dengan tingkat kepuasan pasien di Ruang asoka RSUD dr. R. Koesma Tuban. Meotde: Penelitian ini menggunakan jenis penelitian survei analitik dengan pendekatan cross sectional, sedangkan analisis data yang digunakan adalah uji statistik korelasi Rank Spearman. Populasi yang digunakan dalam penelitian ini adalah pasien di ruang Asoka RSUD dr. R. Koesma Tuban yang sesuai dengan kriteria inklusi sebanyak 155, dengan besar sampel penelitian 112 responden dengan menggunakan teknik simple random sampling. Hasil: Hasil penelitian didapatkan sebagian besar pasien merasa cukup puas dengan pelayanan keperawatan yang cukup baik. Hasil Uji Korelasi Spearmen ( $r_{s}$ didapatkan, variabel mutu pelayanan keperawatan $(p<0,05)$ mempunyai hubungan terhadap tingkat kepuasan pasien dengan korelasi sedang $(r=0,476)$ dan arah korelasi positif yang berarti semakin baik mutu pelayanan keperawatan maka semakin tinggi tingkat kepuasan pasien. Kesimpulan: Hampir setengah dari total perawat di ruang Asoka RSUD dr. R. Koesma Tuban memiliki mutu pelayanan keperawatan yang cukup baik; hampir setengah dari total pasien merasa cukup puas dengan pelayanan keperawatan yang diperoleh; Ada hubungan mutu hubungan pelayanan keperawatan dengan tingkat kepuasan pasien di ruang Asoka RSUD dr. R. Koesma Tuban
\end{abstract}

Kata kunci : Mutu Pelayanan Keperawatan, Kualitas Pelayanan, Tingkat Kepuasan Pasien

\begin{abstract}
The lack of patient satisfaction is due to the increasing demands of the patient's needs, but this is not accompanied by improvements in nurses' actions. If the customer feels dissatisfied with a service provided, then that service can be ascertained to be ineffective and inefficient. This is especially important for public services. Providing services to the community as done by RSUD Dr. R. Koesma Tuban, needs to get attention, especially in the quality of services to suit the needs and expectations of the community. This study focuses on the quality of nursing services and the level of patient satisfaction in the Asoka Hospital Dr. R. Koesma Tuban. This study aims to determine the relationship between the quality of nursing services with the level of patient satisfaction in the Asoka Hospital Dr. R. Koesma Tuban. This study uses analytic survey research with cross sectional approach, while the data analysis used is the Spearman Rank correlation test. The population used in this study were patients in the Asoka room of RSUD dr. R. Koesma Tuban who fit the inclusion criteria as many as 155, with a large sample of 112 respondents using a simple random sampling technique. The results showed that most patients were quite satisfied with the quite good nursing services. Spearmen Correlation Test Results ( $r s)$ obtained, the variable quality of nursing services ( $p$ $<0.05)$ has a relationship to the level of patient satisfaction with moderate correlation $(r=0.476)$ and the direction of the positive correlation which means the better the quality of nursing services, the higher the level of satisfaction patient.Almost half of the nurses at Asoka Room RSUD dr. R. Koesma Tuba have a good quality nursing service. Almost half of the patient at Asoka Room RSUD dr. R. Koesma Tuban feel satisfy with nurse's service; there is a correlation between the quality of nurse service and the level of patient satisfaction at Asoka Room RSUD dr. R. Koesma Tuban.
\end{abstract}

Keywords: Quality of Nursing Services, Level of Patient Satisfaction

*Korespondensi Author : Tiara Putri Ryandini, STIKES Nahdlatul Ulama Tuban, tiaraputriryandini16@gmail.com,Telp.081326634660 


\section{PENDAHULUAN}

Kepuasan dimulai dari penerimaan terhadap pasien dari pertama kali datang sampai meninggalkan rumah sakit. Pasien dikatakan puas jika pelayanan yang diterima oleh pasien sesuai dengan harapan pasien atau melampaui harapan yang pasien inginkan dan jika pelayanan yang diterima oleh pasien tidak sesuai harapan maka sebaliknya pasien tidak puas $^{2}$. Keadaan kurangnya kepuasan pasien terjadi karena tuntutan kebutuhan pasien semakin meningkat, namun tidak diiringi dengan perbaikan tindakan perawat. ${ }^{1}$ Oleh karena itu pelayanan rumah sakit seringkali mengalami permasalahan yang mencakup tentang ketidakpuasan masyarakat terhadap pelayanan dirawat inap dan rawat jalan yang dianggap kurang memadai atau memuaskan. ${ }^{2}$

Responden pasien yang sedang menjalani rawat inap disalah satu rumah sakit Amerika Serikat, sejumlah 150 pasien ditemukan bahwa sekitar 65\% memberikan persepsi negatif terhadap pelayanan perawat di rumah sakit dan $35 \%$ pasien mengatakan puas dengan pelayanan perawat dan sisanya mengatakan tidak puas. Berdasarkan data kepuasan pasien di rawat inap RSUD dr. R. Koesma Tuban pada tahun 2014 yaitu 79,64\% dikategorikan B (baik) dan meningkat pada tahun 2015 mencapai $83,11 \%$ dikategorikan A (sangat baik) dan menurun pada tahun 2016 yaitu 79,47\% dikategorikan B (baik).

Survei awal yang dilakukan oleh peneliti di ruang Asoka RSUD dr. R. Koesma Tuban pada bulan Januari 2019, dengan cara observasi kepada 5 responden $(100 \%)$ pasien. ${ }^{3}$ Didapatkan hasil 2 responden (40\%) mengatakan tidak puas dengan pelayanan dan proses tindakan keperawatan yang di terima diruang Asoka RSUD dr. R. Koesma Tuban, dan 3 responden $(60 \%)$ mengatakan puas.

Pasien dalam mengevaluasi kepuasan terhadap jasa pelayanan yang diterima mengacu pada beberapa faktor, antara lain kualitas produk atau jasa, harga, emosional, kinerja, estetika, karakteristik produk, pelayanan, lokasi, fasilitas, komunikasi, suasana, dan desain visual. Rumah sakit dinyatakan berhasil tidaknya hanya pada kelengkapan fasilitas yang diunggulkan, selain sikap dan pelayanan kesehatan yang diberikan pada pasien juga berpengaruh terhadap pelayanan. ${ }^{4} \quad$ Bila pelayanan kesehatan tersebut diabaikan maka rumah sakit akan kehilangan banyak pasien dan dijauhi oleh calon pasien, hal tersebut dikarenakan pasien merupakan hal yang paling berpengaruh dalam mengembangkan industri rumah sakit. Kepuasan muncul dari kesan pertama pasien masuk ke rumah sakit. ${ }^{5}$ Tuntutan masyarakat atas pelayanan keperawatan yang semakin meningkat membuat perawat sebagai profesi mempunyai andil dan tanggung jawab besar dalam memberikan pelayanan keperawatan yang berkualitas. Dalam tataran pelayanan kesehatan di puskesmas dan di rumah sakit perawat menjadi kunci keberhasilan dalam menyelenggarakan pelayanan kesehatan. Perawat mempunyai konstribusi yang sangat besar dalam tataran tersebut. $^{6}$

Pelayanan di ruang Asoka RSUD dr. R. Koesma Tuban sendiri sudah masuk dalam kategori yang lumayan bagus akan tetapi dalam pemberian tindakan keperawatan dirasa kurang tepat hal itu dikarenakan waktu untuk tindakan keperawatan terkadang tidak sesuai dengan jadwal yang sudah ditentukan, hal itu sering dikeluhkan oleh pasien maupun keluarga pasien bahkan dari pihak pasien sering menanyakan atau bahkan mengingatkan hal tersebut. Dari hal tersebut mengakibatkan nilai kepuasan dalam pemberian pelayanan keperawatan diruang Asoka RSUD dr. R. Koesma tuban dirasa kurang oleh pasien maupun keluarga pasien yang pernah dirawat di ruang tersebut.

Kepuasan muncul dari kesan pertama masuk pasien terhadap pelayanan keperawatan yang diberikan. Misalnya pelayanan yang cepat, tanggap dan keramahan dalam memberikan pelayanan keperawatan. Pelayanan dalam hal ini adalah pelayanan keperawatan yang diterima oleh pasien. Kebutuhan pasien terhadap pelayanan kesehatan yang semakin kompleks akan menuntut pelayanan kesehatan yang profesional dalam mengatasi masalah kesehatan. Pelayanan keperawatan memiliki 
peranan yang penting dalam pelaksanaan pelayanan kesehatan di rumah sakit dimana secara keseluruhan terutama rumah sakit. Jumlah tenaga perawat merupakan tenaga paling banyak bila dibandingkan dengan tenaga kesehatan lainnya, sehingga perannya menjadi penentu dalam pelayanan kesehatan baik di rumah sakit maupun puskesmas. Selain itu, perawat lebih banyak berinteraksi dengan pasien selama 24 jam untuk melaksanakan layanan keperawatan. Keberhasilan pelayanan rumah sakit sangat tergantung pada kinerja perawat rumah sakit dalam melaksanakan layanan keperawatan di rumah sakit yang akan mempengaruhi kepuasan pasien. ${ }^{6}$

Setiap rumah sakit dituntut harus dan mampu mewujudkan pelayanan yang efisien, efektif dan bermutu secara paripurna serta berorientasi kepada kepuasan pasien. Adapun salah satu upaya yang dapat dilakukan demi memenangkan persaingan ini adalah dengan memberikan pelayanan yang berkualitas. Perawat harus meningkatkan pelayanan kepada pasien dengan menunjukkan rasa penerimaan yang baik terhadap pasien dan keluarga pasien dengan sikap selalu ramah, perawat dalam memberikan pelayanan keperawatan harus sabar bersedia memberi memberikan pertolongan kepada pasien, sikap perawat selalu jujur, tekun dalam tugas, sikap perawat harus mampu melakukan komunikasi sebaik mungkin dengan pasien, sikap perawat yang harus mampu melakukan kerjasama yang baik dengan pasien dan keluarga pasien. Selain itu perawat juga dituntut untuk lebih baik lagi dalam melaksanakan asuhan keperawatan yang diberikan terhadap pasien, salah satunya adalah dalam pelaksanaan implementasi keperawatan, dalam tahapan ini terdiri dari 3 aspek yaitu tahap persiapan, perncanaan,dan tahap terminasi, 3 tahap tersebut merupakan bagian yang mempunyai peranan penting dalam memberikan nilai kepuasan bagi pasien maupun keluaga pasien yang berada di ruang Asoka RSUD dr. R. Koesma Tuban.

Berdasarkan uraian tersebut diatas yang melatar belakangi penulis melakukan penelitian dengan judul Hubungan Mutu Pelayanan
Keperawatan dengan Tingkat Kepuasan Pasien di Ruang Asoka RSUD dr. R. Koesma Tuban

\section{METODOLOGI}

Penelitian ini menggunakan metode penelitian Analitic Corelational untuk menganalisis hubungan antar kedua variabel dengan menggunakan pendekatan waktu Cross Sectional dan teknik penelitian menggunakan metode Random Sampling. Populasi dalam penelitian ini adalah pasien yang di rawat di ruang asoka RSUD dr. R. Koesma Tuban sebanyak 155 pasien. Dalam penelitian sampel yang digunakan sebanyak 112 responden pasien di ruang asoka RSUD dr. R. Koesma Tuban. Variabel bebas dalam penelitian ini adalah mutu pelayanan keperawatan sedangkan variabel terikatnya yaitu tingkat kepuasan pasien. Instrumen yang digunakan dalam penelitian ini adalah kuesioner yaitu kuesioner mutu pelayanan keperawatan dan kuesioner tingkat kepuasan pasien.

Penelitian ini menggunakan Analisa bivariate dengan data yang berskala ordinal dan ordinal, serta pengolahan data menggunakan Uji Spearmen Rank. Adapun ketentuan pengambilan keputusan apakah hipotesis diterima atau ditolak dengan melihat signifikan. Bila p $(<0,05)$ maka analisis menunjukkan hasil yang signifikan, dengan penyataan lain $\mathrm{H} 1$ diterima, maka terdapat hubungan mutu pelayanan keperawatan dan tingkat kepuasan pasien di ruang asoka RSUD dr. R. Koesma Tuban.

\section{HASIL DAN PEMBAHASAN}

Berikut ini adalah Distribusi Responden berdasarkan Usia di Ruang Asoka RSUD dr. R Koesma Tuban pada bulan MaretApril Tahun 2019.

Responden berdasarkan Usia di Ruang Asoka RSUD dr. R Koesma Tuban pada bulan Maret-April Tahun

\begin{tabular}{cccc}
\multicolumn{3}{c}{2019} \\
\hline No. & Usia (tahun) & $\boldsymbol{f}$ & $\mathbf{\%}$ \\
\hline 1. & $\leq 20$ & 2 & 1.8 \\
2. & $21-30$ & 6 & 5.4 \\
3. & $31-40$ & 17 & 15.2 \\
4 & $41-50$ & 33 & 29.5 \\
5 & $\geq 50$ & 54 & 48,1
\end{tabular}




\begin{tabular}{rll}
\hline Total & 112 & $100 \%$ \\
\hline
\end{tabular}

Tabel 1 menjelaskan bahwa hampir setengahnya responden berusia $\geq 50$ tahun yaitu sejumlah 54 orang $(48,1 \%)$ dan sebagian kecil responden berumur $\leq 20$ tahun yaitu sejumlah 2 orang $(1,8 \%)$.

Tabel 2. Distribusi Responden berdasarkan Tingkat Pendidikan di Ruang Asoka RSUD dr. R. Koesma Tuban pada Bulan Maret-April Tahun 2019

\begin{tabular}{cccc}
\hline No. & Tingkat Pendidikan & $\boldsymbol{f}$ & $\mathbf{\%}$ \\
\hline 1. & Tidak Sekolah & 2 & 1,8 \\
2. & SD & 52 & 46,4 \\
3 & SMP & 33 & 29,5 \\
4 & SMA & 24 & 21,4 \\
5 & D3/Sarjana & 1 & 0,9 \\
\hline & Total & 112 & $100 \%$ \\
\hline
\end{tabular}

Tabel 2 bahwa hampir setengahnya pendidikan responden adalah SD yang berjumlah 52 orang $(46,4 \%)$, dan sebagian kecil pendidikan responden adalah D3/Sarjana yang berjumlah 1 orang $(0,9 \%)$.

Tabel 3. Distribusi Responden berdasarkan Mutu Pelayanan Keperawatan di Ruang Asoka RSUD dr. R. Koesma Tuban pada Bulan Maret-April Tahun 2019

\begin{tabular}{cccc}
\hline No. & $\begin{array}{c}\text { Pelayanan } \\
\text { Keperawatan }\end{array}$ & $\boldsymbol{f}$ & $\mathbf{\%}$ \\
\hline 1. & Baik & 27 & 24,1 \\
2. & Cukup & 69 & 61,6 \\
3 & Kurang & 16 & 14,3 \\
\hline & Total & 112 & $100 \%$ \\
\hline
\end{tabular}

Tabel 3 menjelaskan bahwa sebagian besar perawat di ruang Asoka melakukan pelayanan keperawatan yang cukup baik yaitu $69(61,6 \%)$ sedangkan perawat dengan pelayanan keperawatan yang baik yaitu 27 $(24,1 \%)$, dan sebagian kecil perawat yang melakukan pelayanan keperawatan yang kurang baik yaitu $16(14,3 \%)$.

Berdasarkan tabel 3 menunjukkan bahwa sebagian besar perawat di ruang asoka RSUD dr. R. Koesma Tuban menerapkan pelayanan keperawatan yang cukup baik yaitu 69 responden $(61,6 \%)$ pada tahap persiapan, dan sebagian kecil menerapkan pelayanan keperawatan yang kurang baik yaitu 16 responden $(14,3 \%)$ pada tahap pelaksanaan.
Layanan keperawatan dapat diamati dari praktik keperawatan yang dilakukan oleh perawat saat melakukan tindakan keperawatan pada pasien. Tindakan perawat hendaknya dilakukan sesuai harapan pasien untuk mencapai tingkat kepuasan dan memenuhi harapan pasien. ${ }^{3}$

Pelayanan kesehatan yang bermutu sering dipersepsikan sebagai suatu layanan kesehatan yang dibutuhkan dalam hal ini akan ditentukan oleh profesi layanan kesehatan dan sekaligus diinginkan baik oleh klien (individu) ataupun masyarakat serta terjangkau oleh daya beli masyarakat. Layanan kesehatan sebagaimana juga mutu barang dan jasa bersifat multidimensi. Terdapat beberapa faktor yang mendukung berjalannya suatu pelayanan dengan baik, yaitu kesadaran para pejabat dan petugas yang berkecimpung dalam pelayanan, aturan yang menjadi landasan kerja pelayanan, organisasi yang merupakan alat serta sistem yang memungkinkan berjalannya mekanisme kegiatan pelayanan, keterampilan petugas berhubungan dengan bagaimana cara petugas mengikuti standart pelayanan yang telah ditetapkan dalam hal kepatuhan, ketepatan (accuracy), kebenaran (reliability), dan konsistensi, dan sarana dalam pelaksanaan tugas pelayanan. ${ }^{8}$

Proses keperawatan adalah proses yang terdiri dari 5 tahap yang spesifik, yaitu pengkajian, diagnosis keperawatan, perencanaan, implemetasi dan evaluasi. ${ }^{8}$ Implementasi keperawatan adalah serangkaian kegiatan yang dilakukan oleh perawat untuk membantu klien dari masalah status keshatan yang dihadapi ke status kesehatan yang lebih baik yang emnggambarkan kriteria hasil yang di harapkan. ${ }^{3}$ Secara operasional hal-hal yang perlu diperhatikan perawat dalam pelaksanaan implementasi keperawatan adalah tahap persiapan meliputi memahami rencana keperawatan secara baik, menguasai keterampilan teknis keperawatan, memahami rasional ilmiah dari tindakan yang akan dilakukan, mengetahui sumber daya yang diperlukan, memahami kode etik dan aspek hukum yang berlaku dalam pelayanan keperawatan, memahami standar praktik klinik keperawatan untuk mengukur keberhasilan, tahap pelaksanaan meliputi mengkomunikasikan atau menginformasikan kepada klien tentang keputusan tindakan keperawatan yang akan dilakukan oleh perawat, 
beri kesempatan kepada klien untuk mengekspresikan perasaannya terhadap penjelasan yang telah diberikan oleh perawat, menerapkan pengetahuan intelektual, kemampuan hubungan antar manusia dan kemampuan teknis keperawatan dalam pelaksanaan tindakan keperawatan yang diberikan oleh perawat, hal-hal yang perlu diperhatikan pada saat pelaksanaan tindakan adalah energi klien, pencegahan kecelakaan dan komplikasi, rasa aman, privasi, kondisi klien, respon klien terhadap tindakan yang telah diberikan, dan pada tahap terminasi meliputi terus memperhatikan respons klien terhadap tindakan keperawatan yang telah diberikan, tinjau kemajuan klien dari tindakan keperawatan yang telah diberikan, rapikan peralatan dan lingkungan klien dan lakukan terminasi.

Berdasarkan hasil penelitian ini pelayanan keperawatan di ruang asoka sudah cukup baik pada tahap persiapan karena perawat terampil berhubungan dengan bagaimana cara perawat mengikuti standart pelayanan yang telah ditetapkan dalam hal kepatuhan, ketepatan, kebenaran, dan konsistensi dalam melakukan persiapan sebelum melakukan tindakan keperawatan kepada pasien, dan dengan melihat beberapa item yang terdapat pada kuesioner, yaitu sebagian besar responden menilai perawat dalam memberi pelayanan keperawatan yaitu cukup baik yang mendapat nilai paling tinggi yaitu pada tahap persiapan, pada tahap persiapan ini perawat terlihat sudah siap mulai dari diri dan alat yang diperlukan dalam hal ini beberapa responden mengungkapkan bahwa perawat tidak terlihat bolak balik ke ruang perawat untuk mengambil alat tetapi pada tahap pelaksanaan mengalami penurunan yaitu berdasarkan ungkapan dari responden perawat tidak memperhatikan keadaan pasien saat melakukan tindakan keperawatan dalam hal ini pasien merasa kurang nyaman begitu pula pada tahap terminasi responden mengungkapkan perawat setelah melakukan tindakan keperawatan tidak memperhatikan perkembangan klien. Dapat disimpulkan bahwa pada tindakan pelayanan keperawatan pada tahap persiapan perawat sudah cukup bagus tetapi menurun pada tahap pelaksanaan dan terminasi.
Tabel 4. Distribusi Responden berdasarkan Tingkat Kepuasan Pasien di Ruang Asoka RSUD dr. R. Koesma Tuban pada Bulan Maret-April Tahun 2019

\begin{tabular}{|c|c|c|c|}
\hline No. & Kepuasan Pasien & $f$ & $\%$ \\
\hline 1. & Tinggi & 36 & 32,1 \\
\hline 2. & Sedang & 64 & 57,1 \\
\hline \multirow[t]{2}{*}{3} & Rendah & 12 & 10,7 \\
\hline & Total & 112 & $100 \%$ \\
\hline
\end{tabular}

Berdasarkan tabel 4 menjelaskan bahwa hampir setengahnya pasien yang di rawat di ruang Asoka tingkat kepuasannya sedang atau pasien merasa cukup puas sejumlah 64 pasien $(57,1 \%)$, sedangkan untuk tingkat kepuasan tinggi atau pasien merasa sangat puas yaitu 36 pasien $(32,1 \%)$ dan sebagian kecil pasien yang merasa tidak puas atau tingkat kepuasan rendah sejumlah 12 pasien (10,7\%).

Berdasarkan tabel 4 menjelaskan bahwa sebagian besar pasien yang di rawat di ruang Asoka menilai tingkat kepuasan sedang atau pasien merasa cukup puas sejumlah 64 responden $(57,1 \%)$, dan kepuasan pasien tinggi atau pasien merasa sangat puas 36 responden (32,1 dan sebagian kecil pasien yang merasa tidak puas atau tingkat kepuasan rendah sejumlah 12 pasien $(10,7 \%)$.

Pasien dalam mengevaluasi kepuasan terhadap jasa pelayanan yang diterima mengacu pada beberapa faktor yaitu kualitas produk atau jasa yaitu pasien akan merasa puas bila hasil evaluasi mereka menunjukan bahwa produk atau jasa yang digunakan berkualitas, harga merupakan aspek penting, namun yang terpenting dalam penentuan kualitas guna mencapai kepuasan pasien elemen ini mempengaruhi pasien dari segi biaya yang di keluarkan, biasanya semakin mahal harga perawatan maka pasien mempunyai harapan yang lebih besar, emosional yaitu pasien yang merasa bangga dan yakin bahwa orang lain kagum terhadap konsumen bila dalam hal ini pasien memilih institusi pelayanan kesehatan yang sudah mempunyai pandangan, cenderung memiliki tingkat kepuasan yang lebih tinggi, kinerja yaitu wujud dari kinerja ini misalnya kecepatan, kemudahan, dan kenyamanan dalam memberikan pelayanan yang relative cepat, karakteristik produk meliputi meliputi penampilan bangunan, kebersihan dan tipe kelas kamar yang disediakan beserta kelengkapannya, pelayanan yaitu pelayanan keramahan petugas rumah sakit, kecepatan dalam pelayanan. Institusi pelayanan kesehatan dianggap baik apabila dalam memberikan 
pelayanan lebih memperhatikan kebutuhan pasien. Kepuasan muncul dari kesan pertama masuk pasien terhadap pelayanan keperawatan yang diberikan. Misalnya pelayanan yang cepat, tanggap dan keramahan dalam memberikan pelayanan keperawatan, lokasi yaitu umumnya semakin dekat lokasi dengan pusat perkotaan atau yang mudah dijangkau, mudahnya transportasi dan lingkungan yang baik akan semakin menjadi pilihan bagi pasien, fasilitas turut menentukan kepuasan pasien, misalnya fasilitas kesehatan baik sarana dan prasarana, tempat parkir, ruang tunggu yang nyaman dan ruang kamar rawat inap, komunikasi yaitu tata cara informasi yang diberikan pihak penyedia jasa dan keluhan dari pasien, suasana meliputi keamanan dan keakraban. Suasana yang tenang, nyaman, sejuk dan indah akan sangat mempengaruhi kepuasan pasien dalam proses penyembuhannya, desain visual meliputi dekorasi ruangan, bangunan dan desain jalan yang tidak rumit. Tata ruang dan dekorasi ikut menentukan suatu kenyamanan.

Kepuasan adalah perasaan senang seseorang yang berasal dari perbandingan antara kesenangan terhadap aktivitas dan suatu produk dengan harapannya. Kepuasan adalah perasaan senang atau kecewa seseorang yang muncul setelah membandingkan antara persepsi atau kesannya terhadap kinerja atau suatu produk dan harapan-harapannya. ${ }^{2}$ Kualitas pelayanan yang berkaitan dengan kepuasan ditentukan oleh lima unsur yang biasa dikenal dengan istilah "RATER" (responsiveness, assurance, tangible, emphaty, dan reliability). ${ }^{1}$

Berdasarkan hasil penelitian ini bahwa diruang asoka kepuasan pasien dalam kategori sedang karena kinerja dan pelayanan perawat dalam memberikan tindakan keperawatan yang relatif kurang tanggap atau cukup lama sehingga pasien tidak cukup puas dengan kinerja pelayanan yang diberikan, dalam hal ini kepuasan pasien sangat pengaruhi oleh faktor pelayanan yang diberikan perawat. Kepuasan responden hanya berada kategori sedang mungkin dikarenakan juga dari pengalaman responden yang pernah memanfaatkan RSUD dr. R. Koesma Tuban dalam mengatasi masalah kesehatannya. Pengalaman tersebut dapat mempengaruhi penilaian responden menjadi biasa saja pada layanan yang baik maupun yang kurang baik. dilihat dari segi karakteristik layanan, kemungkinan perawat memberikan layanan yang sewajarnya, tidak memberikan layanan yang eksklusif maupun tidak memberikan layanan yang kurang baik. faktor lain yang menyebabkan tingkat kepuasan sedang adalah keadaan responden saat menjawab kuesioner.

Kemungkinan responden kurang semangat dalam mengisi kuesioner sehingga responden mengisi dengan asal-asalan. Hal ini selaras bahwa faktor emosional mempengaruhi tingkat kepuasan pasien. ${ }^{7}$ Berdasarkan dengan melihat beberapa item yang terdapat pada kuesioner bahwa responden menyatakan mereka merasakan kepuasan tinggi pada faktor assurance dan responden merasakan tidak puas atau kepuasan rendah pada faktor responsiveness hal ini di ungkapkan oleh responden karena pada saat pasien datang ke rumah sakit pasien berharap tinggi terhadap pelayanan yang akan diterimanya dan pada kenyataannya tidak sebanding dengan pelayanan keperawatan yang diterimanya dalam hal ini perawat kurang tanggap atau terlalu lama dalam memberikan tindakan, sehingga harapan tinggi pasien berkurang pada faktor daya tanggap.

Tabel 5. Mutu Pelayanan Keperawatan Dengan

Tingkat Kepuasan Pasien di Ruang Asoka

RSUD dr. R. Koesma Tuban pada Bulan MaretApril Tahun 2019

\begin{tabular}{ccccc}
\hline $\begin{array}{c}\text { Pelayanan } \\
\text { Keperawata } \\
\mathbf{n}\end{array}$ & \multicolumn{2}{c}{ Kepuasan Pasien } & \multirow{2}{*}{ Total } \\
\cline { 2 - 4 } Kurang & $7(43,7 \%)$ & $8(50 \%)$ & $1(6,2 \%)$ & $16(100 \%)$ \\
Cukup & $5(7,2 \%)$ & $46(66,6 \%)$ & $18(26 \%)$ & $69(100 \%)$ \\
Baik & $0(0 \%)$ & $10(37 \%)$ & $17(62,9 \%)$ & $27(100 \%)$ \\
\hline Total & $12(10,7 \%)$ & $64(57,1 \%)$ & $36(32,1 \%)$ & 112 \\
\hline $\begin{array}{l}\text { Hasil Uji korelasi Spearman Rank } \\
\text { Nilai r }=0,476\end{array}$ & $\rho=0,000$ & & \\
\hline
\end{tabular}

Berdasarkan tabel 5 diketahui bahwa kepuasan pasien sedang dengan pelayanan keperawatan yang cukup yaitu sejumlah 46 $(66,6 \%)$, sedangkan kepuasan pasien tinggi dengan pelayanan keperawatan yang baik sejumlah $17(62,9 \%)$ dan kepuasan pasien rendah dengan pelayanan keperawatan yang kurang sejumlah 7 (43,7\%).

Berdasarkan tabel 5 Hal ini dibuktikan dengan analisa menggunakan program SPSS dengan uji korelasi spearman rank dan tingkat signifikansi $(\alpha) \quad 0,05$ didapatkan $\rho=0,00$ dimana $\rho<0,05$ maka disimpulkan H1 diterima, artinya ada hubungan antara Pelayanan Keperawatan dengan Kepuasan Pasien di Ruang Asoka RSUD dr. R. Koesma 
Tuban. Selain itu didapatkan nilai korelasi spearman $=0,476$ yang menunjukkan bahwa arah korelasi positif dengan kekuatan korelasi yang sedang antara mutu Pelayanan Keperawatan dengan tingkat Kepuasan Pasien di Ruang Asoka RSUD dr. R. Koesma Tuban. Dengan kata lain semakin baik pelayanan keperawatan maka semakin tinggi kepuasan yang dirasakan pasien, begitu pula sebaliknya. Sejalan dengan terdapat hubungan korelasi positif sebesar 0,529 antara kualitas pelayanan tenaga perawat dengan tingkat kepuasan pasien diruang rawat inap badan RSUD dr. $H$. Soewondo Kendal. ${ }^{9}$

Kepuasan pelanggan (pasien) terjadi apabila apa yang menjadi kebutuhan, keinginan, atau harapannya dapat terpenuhi. Harapan tersebut dapat terpenuhi melalui jasa (pelayanan kesehatan) yang diterima olehnya. Oleh karena itu kepuasan pasien adalah selisih (gap) antara layanan yang diterima oleh pasien dengan harapan pasien pada layanan tersebut. ${ }^{4}$

Pasien dalam mengevaluasi kepuasan terhadap jasa pelayanan yang diterima mengacu pada beberapa faktor yaitu kualitas produk atau jasa, harga, emosional, kinerja, estetika, karakteristik produk, pelayanan, lokasi, fasilitas, komunikasi, suasana, desain visual. ${ }^{8}$

Mengevaluasi jasa yang bersifat intangible, konsumen umumnya menggunakan beberapa atribut atau faktor kepuasan meliputi bukti langsung (Tangible), keandalan (Reability), Daya tanggap (Responsiveness), jaminan (Assurance), dan empati. ${ }^{2}$

Hasil penelitian menunjukkan bahwa hipotesis pada penelitian ini diterima yaitu ada hubungan mutu pelayanan keperawatan dengan tingkat kepuasan pasien. terdapat hasil penelitian tentang pelayanan keperawatan dengan tingkat kepuasan yang mendukung hasil penelitian ini, yaitu penelitian dengan judul "Hubungan Kualitas Pelayanan Tenaga Perawat dengan Tingkat Kepuasan Pasien di Ruang Rawat Inap Badan RSUD dr. H. Soewondo Kendal". ${ }^{7}$ Hasil penelitian tersebut juga menunjukkan bahwa ada hubungan yang bermakna antara persepsi pasien terhadap mutu pelayanan dengan kepuasan pasien.
Berdasarkan hasil penelitian di atas dapat memperkuat teori yang dikemukakan bahwa pelayanan merupakan hal terpenting dari faktorfaktor yang mempengaruhi kepuasan pasien. ${ }^{8}$ Pelayanan kesehatan khususnya pelayanan keperawatan harus kompeten dan memperhatikan kebutuhan pasien dan menghargai pasien. Pelayanan yang memberikan kesan baik akan meningkatkan kepuasan pasien.

Hasil penelitian di Ruang Asoka RSUD dr. R. Koesma Tuban bahwa ada responden yang menilai pelayanan keperawatan berada pada kategori kurang namun tingkat kepuasan tinggi sejumlah 1 orang. Peneliti menganalisa penyebab responden menyatakan kepuasannya tinggi dengan pelayanan yang kurang dikarenakan responden merasa lelah dan kurang bersemangat dalam mengisi kuesioner sehingga responden dalam mengisi kuesioner asal-asalan. Hal ini selaras bahwa faktor emosional mempengaruhi tingkat kepuasan pasien. ${ }^{7}$

Disisi lain masih ada beberapa yang menilai layanan keperawatan pada kategori kurang baik memiliki tingkat kepuasan rendah. Layanan keperawatan yang diterima oleh pasien ternyata kurang dari harapan pasien, maka pasien tersebut merasa tidak puas karena merasa kecewa. Apabila pelayanan keperawatan yang diterima tidak sebanding atau lebih besar dari harapan pasien maka pasien merasa puas. Maka dapat dikatakan bahwa pelayanan keperawatan berhubungan dengan kepuasan yang dirasakan pasien. Semakin baik pelayanan keperawatan, maka kepuasan pasien semakin tinggi pula. Demikian juga sebaliknya, semakin rendah pelayanan keperawatan, maka kepuasan pasien semakin rendah pula.

Dari hasil penelitian pelayanan keperawatan yang baik dari perawat merupakan salah satu sikap yang merupakan unsur yang sangat penting dalam proses yang berlangsung sehingga menciptakan rasa nyaman dan aman dari pasien. Pasien yang diperlakukan dengan penuh kasih sayang, terutama adanya tindakan keperawatan dengan baik akan menghasilkan kesembuhan luka yang lebih cepat, berkurangnya rasa nyeri, berkurangnya 
kecemasan dan mempercepat rawat inap di rumah sakit yang berdampak pada kepuasan pasien.

Tindakan keperawatan yang baik dari perawat dalam melakukan pelayanan keperawatan menjadi salah satu komponen yang utama. Kepuasan pasien merupakan keluaran layanan kesehatan. Dengan demikian kepuasan pasien merupakan salah satu tujuan untuk meningkatkan kualitas pelayanan. Dapat dibuktikan bahwa pasien di Ruang Asoka RSUD dr. R. Koesma Tuban pada bulan MaretApril Tahun 2019 merasa puas terhadap mutu pelayanan keperawatan yang baik terhadap pasien dan keluarga pasien.

\section{SIMPULAN DAN SARAN}

Dari hasil penelitian yang telah dilakukan dapat disimpulkan bahwa:

1. Hampir setengahnya perawat di ruang Asoka RSUD dr. R. Koesma Tuban memiliki mutu pelayanan keperawatan yang cukup baik, hal ini dibuktikan dengan banyaknya pasien maupun keluarga pasien yang mengutarakan hal tersebut.

2. Hampir setengahnya pasien merasa cukup puas dengan pelayanan keperawatan yang diperoleh, hal itu dibuktikan dengan sedikitnya keluhan pasien tentang mutu pelayanan keperawatan yng diterima dari perawat di ruang Asoka RSUD dr. R. Koesma Tuban.

3. Ada hubungan mutu hubungan pelayanan keperawatan dengan tingkat kepuasan pasien di ruang Asoka RSUD dr. R. Koesma Tuban.

\section{SARAN}

1. Bagi Peneliti Selanjutnya

Peneliti selanjutnya sebaiknya mampu mengembangkan penelitian lebih lanjut mengenai masing masing dari komponen variabel kepuasan pasien yaitu reliability, assurance, tangible, emphaty, responsiveness, dengan komponen variabel pelayanan keperawatan meliputi tahap persiapan, tahap pelaksanaan dan tahap terminasi.

2. Bagi Instansi Rumah Sakit
Sebaiknya pihak rumah sakit mempertahankan tahap persiapan dalam tindakan keperawatan dan meningkatkan tahap pelaksanaan dan tahap terminasi dalam pemberian pelayanan keperawatan dengan memperhatikan atau mengkaji faktor penunjang kepuasan pasien yaitu mempertahankan aspek assurance dan meningkatkan aspek tangible dan responsiveness Selain itu meningkatkan kolaborasi dan kepercayaan diri perawat, pengembangan persahabatan dan kebersamaan di lingkungan kerja, meningkatkan dukungan dari tim kerja dan hubungan kerjasama yang lebih harmonis antara atasan dan bawahan serta sesama rekan kerja, pembayaran yang sesuai dengan beban kerja dan tanggung jawab, memberikan pelatihan tingkat lanjut dan kesempatan pengembangan diri dimana setiap perawat diberi kesempatan yang sama, begitu pula memberi kesempatan yang sama untuk promosi karir guna meningkatkan pelayanan keperawatan dan meminimalisir keluhan kepuasan pasien.

\section{Bagi Perawat}

Sebaiknya perawat mempertahankan atau meningkatkan pelayanan keperawatannya dalam rangka meminimalisir keluhan pasien serta meningkatkan ketrampilan dan profesionalisme kerjanya. Selain itu perawat diharapkan dapat mengkomunikasikan keluhankeluhan dengan baik dan sesuai dengan prosedur yang berlaku. Perawat juga dapat memberikan saran dan masukan kepada pihak pengelola rumah sakit secara terbuka pada setiap agenda rapat rutin berkaitan dengan kebijakan-kebijakan yang dirasa kurang sesuai atau perlu dilakukan pembenahan.

\section{UCAPAN TERIMA KASIH}

1. Dr. H. Miftahul Munir, SKM., M.Kes., DIE selaku ketua STIKES Nahdlatul Ulama Tuban

2. Ummu Qonitun, S.SiT., M.Keb., MM., selaku ketua LPPM STIKES Nahdlatul Ulama Tuban

3. Seluruh dosen dan civitas akademika STIKES Nahdlatul Ulama Tuban 


\section{REFERENSI}

1. Ehsan MM, Ghafoor MM, Iqbal, HK. Impact of brand image, service quality and price on customer satisfaction. International Journal of Business and Social Science. 2012; (3): 23.

2. Nursalam. Manajemen keperawatan. Jakarta: Salemba Medika; 2015.

3. Tjiptono, Fandy dan Gregorius Chandra. Service Quality and Satisfaction, Edisi 4. Penerbit Andi: Yogyakarta; 2016.

4. S. Supriyanto dan Ernawati. Pemasaran industri jasa kesehatan. Penerbit CV Andi Offset: Yogyakarta; 2010.
5. Triwibowo. Manajemen pelayanan keperawatan di rumah sakit. TIM: Jakarta; 2013.

6. Asmuji. Manajemen keperawatan. Ar-Ruzz Media: Yogyakarta; 2012.

7. Ertanto, W. Hubungan antara kualitas pelayanan tenaga perawat dengan tingkat kepuasan pasien di ruang rawat inap badan rumah sakit umum dr. H. Soewondo Kendal. 2002. Available from:http://eprints.undip.ac.id/6687/1/1395.pdf.

8. Moenir. Manajemen pelayanan umum di indonesia. PT. Bumi Aksara: Jakarta; 2002.

9. Simamora, R. Buku ajar manajemen keperawatan. EGC: Jakarta; 2015. 